\title{
Isotopic Analysis of Sporocarp Protein and Structural Material Improves Resolution of Fungal Carbon Sources
}

OPEN ACCESS

Edited by:

Sharon Lafferty Doty,

University of Washington, USA

Reviewed by:

Sébastien Duperron,

Pierre-and-Marie-Curie University

(UPMC), France

Horst Felbeck,

University of California, San Diego,

USA

${ }^{*}$ Correspondence:

Janet Chen

Janet.chen@unh.edu

Specialty section:

This article was submitted to

Microbial Symbioses,

a section of the journal

Frontiers in Microbiology

Received: 30 September 2016 Accepted: 28 November 2016

Published: 26 December 2016

Citation:

Chen J, Hofmockel KS and Hobbie EA (2016) Isotopic Analysis of Sporocarp Protein and Structural Material Improves Resolution

of Fungal Carbon Sources.

Front. Microbiol. 7:1994.

doi: 10.3389/fmicb.2016.01994

\begin{abstract}
Janet Chen ${ }^{1,2 *}$, Kirsten S. Hofmockel ${ }^{3,4}$ and Erik A. Hobbie ${ }^{1}$
${ }^{1}$ Earth, Oceans and Space, Earth Systems Research Center, University of New Hampshire, Durham, NH, USA, ${ }^{2}$ Soil and Water Management and Crop Nutrition Laboratory, FAO/IAEA Agriculture and Biotechnology Laboratories, Seibersdorf, Austria, ${ }^{3}$ Department of Ecology, Evolution and Organismal Biology, lowa State University, Ames, IA, USA, ${ }^{4}$ Environmental Molecular Sciences Laboratory and Biological Sciences Division, Pacific Northwest National Laboratory, Richland, WA, USA
\end{abstract}

Fungal acquisition of resources is difficult to assess in the field. To determine whether fungi received carbon from recent plant photosynthate, litter or soil-derived organic (C:N bonded) nitrogen, we examined differences in $\delta^{13} \mathrm{C}$ among bulk tissue, structural carbon, and protein extracts of sporocarps of three fungal types: saprotrophic fungi, fungi with hydrophobic ectomycorrhizae, or fungi with hydrophilic ectomycorrhizae. Sporocarps were collected from experimental plots of the Duke Free-air $\mathrm{CO}_{2}$ enrichment experiment during and after $\mathrm{CO}_{2}$ enrichment. The differential ${ }^{13} \mathrm{C}$ labeling of ecosystem pools in $\mathrm{CO}_{2}$ enrichment experiments was tracked into fungi and provided novel insights into organic nitrogen use. Specifically, sporocarp $\delta^{13} \mathrm{C}$ as well as $\delta^{15} \mathrm{~N}$ of protein and structural material indicated that fungi with hydrophobic ectomycorrhizae used soil-derived organic nitrogen sources for protein carbon, fungi with hydrophilic ectomycorrhizae used recent plant photosynthates for protein carbon and both fungal groups used photosynthates for structural carbon. Saprotrophic fungi depended on litter produced during fumigation for both protein and structural material.

Keywords: organic nitrogen use, ${ }^{13} \mathrm{C},{ }^{15} \mathrm{~N}$, ectomycorrhizal fungi, saprotrophic fungi, carbon uptake

\section{INTRODUCTION}

Despite the diverse roles that fungi play in carbon cycling in forest ecosystems, little is known about how different fungi partition carbon resources internally. Instead, fungi in forest ecosystems are commonly classified by the substrates they use. Saprotrophic fungi dominate the litter layer (Oi horizon) and decaying material such as litter, cones and wood (Rayner and Boddy, 1988). Ectomycorrhizal fungi are primarily active in the organic horizons below the litter layer, decompose relatively older organic matter for resources, and can transfer acquired nutrients to plants in exchange for plant photoassimilates (Smith and Read, 1997; Lindahl et al., 2007). Ectomycorrhizal fungi can be classified into those with hydrophobic ectomycorrhizae or hydrophilic ectomycorrhizae (Unestam and Sun, 1995; Agerer, 2006) that purportedly can use insoluble or soluble substrates, respectively (Lilleskov et al., 2011; Hobbie et al., 2013b). Specifically, fungi with hydrophobic ectomycorrhizae consist of hyphae with medium to long distance exploration types that can use insoluble as well as soluble substrates and fungi with 
hydrophilic ectomycorrhizae consist of hyphae with contact and shorter distance exploration types that rely on soluble substrates. While these generalized classifications are helpful, quantifying which carbon sources are accessed by specific taxa requires new approaches.

In laboratory studies, fungi can be supplied with specific carbon substrates to determine which ones are preferentially consumed (Tinker et al., 1990; Colpaert et al., 1996; Hobbie et al., 2004). These studies provide insight into fungal uptake capabilities, but they may not represent fungal resource acquisition strategies in the field. In the field, labeling with isotope tracers can track fungal sources of carbon (Ho and Trappe, 1973; Högberg et al., 2010; Hobbie et al., 2014). Such labeling has included elevated atmospheric $\mathrm{CO}_{2}$ experiments, in which ${ }^{13} \mathrm{C}$-depleted $\mathrm{CO}_{2}$ is added to raise $\mathrm{CO}_{2}$ concentrations in free air $\mathrm{CO}_{2}$ enrichment (FACE) studies. Carbon isotope signatures in bulk sporocarp material of ectomycorrhizal and saprotrophic fungi confirmed that both types of fungi rely on carbon recently assimilated by plants and suggested that some ectomycorrhizal fungi also incorporated carbon from soil-derived organic nitrogen sources that predated the ${ }^{13} \mathrm{C}$ labeling (Hobbie et al., 2014). Additional studies have measured isotopic composition of sporocarps at natural abundance levels to determine fungal sources of carbon, with the ${ }^{13} \mathrm{C}:{ }^{12} \mathrm{C}$ ratio $\left({ }^{13} \mathrm{C}\right)$ generally lower for ectomycorrhizal fungi than for saprotrophic fungi (Högberg et al., 1999; Kohzu et al., 1999; Hobbie et al., 2001). The ${ }^{15} \mathrm{~N}:{ }^{14} \mathrm{~N}$ ratio $\left(\delta^{15} \mathrm{~N}\right)$ of fungi has also been used to determine fungal sources of organic (carbon-bonded) nitrogen, since deeper and older forms of organic nitrogen are ${ }^{15} \mathrm{~N}$ enriched relative to shallower and younger organic nitrogen (Billings and Richter, 2006; Hobbie and Ouimette, 2009). This difference in $\delta^{15} \mathrm{~N}$ across soil profiles is largely due to inputs of low $\delta^{15} \mathrm{~N}$ litter higher in the soil profile and decomposition that increases $\delta^{15} \mathrm{~N}$ values deeper down in the soil profile (Nadelhoffer and Fry, 1988), as well as due to fractionation of $\mathrm{N}$ during ecotmycorrhizal transfer of $\mathrm{N}$ to plants (Hobbie and Colpaert, 2003). Studies to date have focused on bulk sporocarps and have given significant but limited insight into fungal sources of carbon.

Isotope analysis of different fungal compounds (e.g., protein, chitin, and lipids) can provide new information about how carbon is allocated, but this has only begun to be studied. Hobbie et al. (2012) suggested that fungal protein was enriched in ${ }^{13} \mathrm{C}$ and ${ }^{15} \mathrm{~N}$ relative to fungal carbohydrates, chitin, and lipids based on bulk isotopic patterns in protein-rich caps relative to protein-poor stipes of sporocarps. Radiocarbon ${ }^{14} \mathrm{C}$ studies on protein and structural material of fungi with hydrophobic and hydrophilic ectomycorrhizae indicate that structural carbon is derived from recent carbon sources, such as photosynthate, while protein carbon can be derived from new photosynthate and from either recent organic nitrogen in the younger Oi horizon or from older organic nitrogen sources in the Oea horizon, depending on the fungal functional group (Hobbie et al., 2013a). Glycoproteins and polysaccharides are the major structural compounds in fungal cell walls that facilitate formation and structure of fungi (Bowman and Free, 2006). Chitin is also an integral component of the fungal cell wall (Bago et al., 1996; Bowman and Free, 2006). Additional proteins are involved in metabolism, protection, growth and maintenance (Persson et al., 1991; Niessing, 2000; Saier, 2000; González-Chávez et al., 2004; Seidl, 2008). Because most carbon is allocated to structural and protein material in fungi (Kalač, 2009), and because of the foundation of these previous studies, structural and protein extracts of sporocarps are good candidates for characterizing carbon acquisition and allocation.

Here we determined sources of ectomycorrhizal and saprotrophic carbon using sporocarps and soil collected from the Duke FACE experiment. $\mathrm{CO}_{2}$-fumigated plots in a Pinus taeda plantation were fumigated with ${ }^{13} \mathrm{C}$-depleted $\mathrm{CO}_{2}$ from 1997 to 2010 (Hendrey et al., 1999). Differences in $\delta^{13} \mathrm{C}$ of bulk tissue, structural carbon, and protein extracts from ambient and FACE treatment plots during and after $\mathrm{CO}_{2}$ enrichment were used to determine whether fungi obtained carbon from recent plant photosynthate, plant litter, or soil-derived organic nitrogen sources. To further clarify whether carbon from soil organic matter was acquired from the younger or older organic soil horizons, patterns of soil and fungal $\delta^{15} \mathrm{~N}$ were also investigated. We predicted that bulk saprotrophic sporocarps collected post- $\mathrm{CO}_{2}$ fumigation from wood decay and litter decay groups would be lower in $\delta^{13} \mathrm{C}$ than ectomycorrhizal fungi due to the acquisition of litter-derived carbon produced during $\mathrm{CO}_{2}$ fumigation. Furthermore, $\delta^{13} \mathrm{C}$ and $\delta^{15} \mathrm{~N}$ patterns in protein and structural carbon of sporocarps tested whether fungi with hydrophobic ectomycorrhizae use soil-derived organic nitrogen sources for protein carbon, fungi with hydrophilic ectomycorrhizae use recent plant photosynthates for protein carbon, and whether both fungal groups depend on plant photosynthates for structural carbon as opposed to saprotrophic fungi relying on recent litter and wood (Figure 1). Specifically, we predicted that protein of fungi with hydrophobic ectomycorrhizae would be lower in $\delta^{13} \mathrm{C}$ than structural material after $\mathrm{CO}_{2}$ fumigation shutoff, reflecting older, deeper organic $\mathrm{N}$ sources, while protein and structural material of fungi with hydrophilic ectomycorrhizae and saprotrophic fungi would be similar, reflecting recent assimilates and surficial litter created before $\mathrm{CO}_{2}$ shutoff. We also predicted that the $\delta^{15} \mathrm{~N}$ of fungi with hydrophobic ectomycorrhizae would be higher than fungi with hydrophilic ectomycorrhizae and saprotrophic fungi, reflecting the differing sources of organic $\mathrm{N}$ in the soil profile.

\section{MATERIALS AND METHODS}

\section{Field Site}

Our work was conducted within the Duke Forest FACE experiment in North Carolina, USA $\left(35^{\circ} 58^{\prime} 41^{\prime \prime} \mathrm{N}, 79^{\circ} 05^{\prime} 39^{\prime \prime}\right.$ $\mathrm{W}, 163 \mathrm{~m}$ elevation). The forest is dominated by loblolly pine (Pinus taeda) that were planted in 1983 as 3-year-old seedlings with $2.4 \mathrm{~m}^{2}$ spacing. Deciduous tree species including Liquidambar styraciflua, Acer rubrum, Cercis Canadensis, and Cornus florida dominate the understory. Three control and three $\mathrm{CO}_{2}$-fumigated plots, $30 \mathrm{~m}$ in diameter, were fumigated with ambient air or $\mathrm{CO}_{2}$ (to 200 ppm above ambient levels), respectively. The $\mathrm{CO}_{2}$ used for fumigation was strongly depleted in ${ }^{13} \mathrm{C}$ relative to atmospheric $\mathrm{CO}_{2}$, with a $\delta^{13} \mathrm{C}$ of $-43.0 \pm 0.6 \%$, 

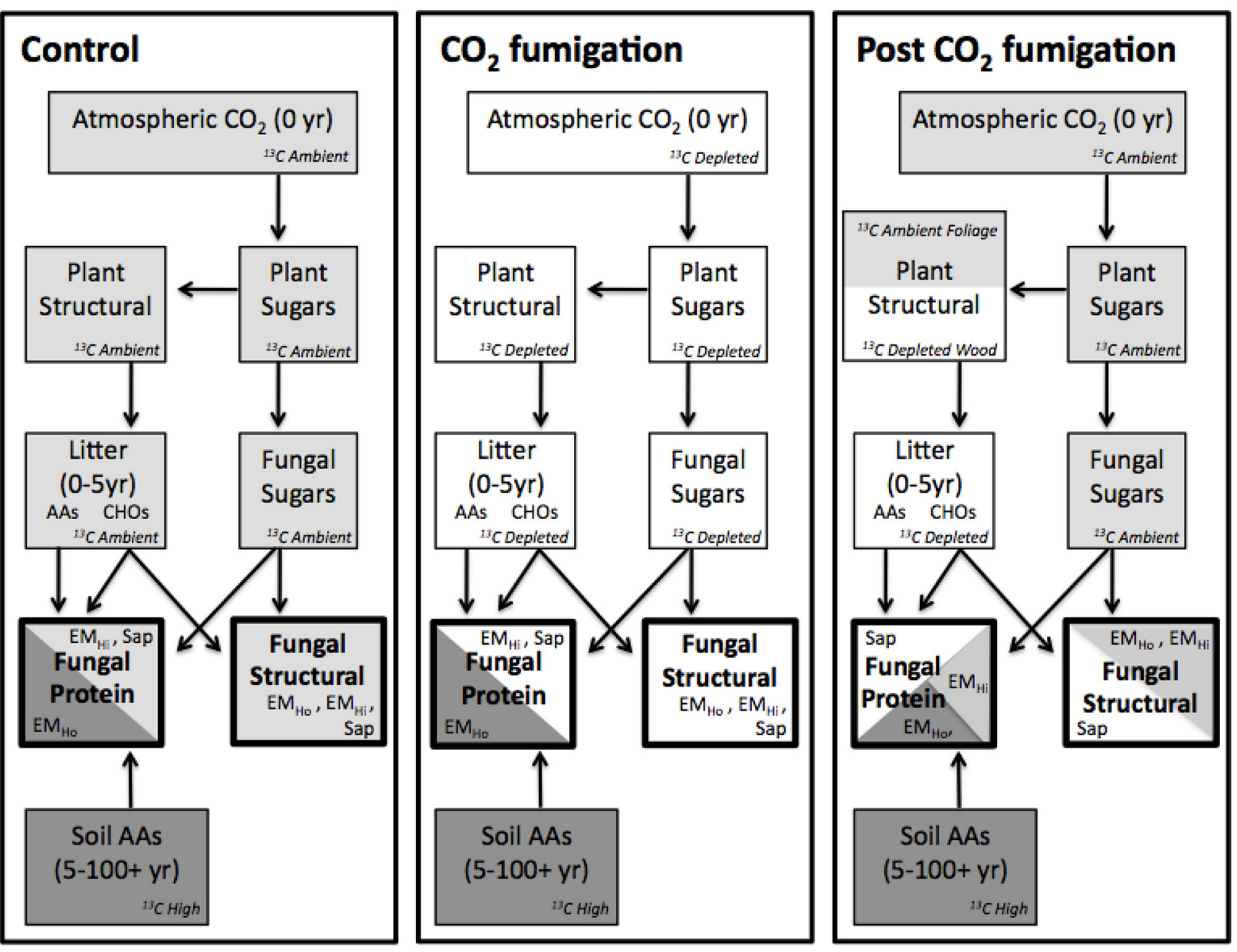

FIGURE 1 | Schematic of carbon fluxes in the plant-fungal-soil system, showing how uptake of recently assimilated carbon and old soil organic nitrogen can influence the $\delta^{13} \mathrm{C}$ of saprotrophic (Sap) fungi of fungi with hydrophilic ectomycorrhizae (EM $\mathbf{H i}_{\boldsymbol{H i}}$ ) and hydrophobic (EM $\left.\mathrm{M}_{\boldsymbol{H o}}\right)$ ectomycorrhizae fungi when carbon sources differ in $\delta^{\mathbf{1 3}} \mathbf{C}$. Scenarios are represented for ambient, $\mathrm{CO}_{2}$-fumigated and previously $\mathrm{CO}$-fumigated FACE plots. AAs $=$ amino acids. ${ }^{13} \mathrm{C}$ high to low from dark gray $>$ light gray $>$ white

thus lowering the $\delta^{13} \mathrm{C}$ of $\mathrm{CO}_{2}$ within the ring by $12 \%$, to $-20 \%$. Fumigation began August 27, 1996 and was continuous until fumigation shutoff on November 1, 2010. A 98 atom $\%{ }^{15} \mathrm{~N}$ tracer $\left(75 \%\right.$ as $\mathrm{NH}_{4} \mathrm{Cl}$ and $25 \%$ as $\mathrm{KNO}_{3}$ at a rate of $15 \mathrm{mg}{ }^{15} \mathrm{~N} \mathrm{~m}^{-2}$ in $0.251 \mathrm{H}_{2} \mathrm{O}$ ) was applied by backpack sprayers to all of each plot in May 2003. This represented 3\% of the inorganic $\mathrm{N}$ pool from 0 to $15 \mathrm{~cm}$ depth. Additionally, in 2005 each FACE plot was divided in half with a plastic sheet to a $70 \mathrm{~cm}$ depth. Half of the plot was fertilized with $56 \mathrm{~kg} \mathrm{ha}^{-1}$ unlabeled $\mathrm{NH}_{4} \mathrm{NO}_{3}$ twice, in March and April 2005, and then in one annual application in March until $\mathrm{CO}_{2}$ fumigation shutoff in 2010. Although the added ${ }^{15} \mathrm{~N}$ label in our plots raised ${ }^{15} \mathrm{~N}$ levels in our sporocarps compared to other studies without a tracer addition and raised $\delta^{15} \mathrm{~N}$ of the Oea soil horizon relative to mineral soils, we were still able to compare $\delta^{15} \mathrm{~N}$ values between fungal types, $\mathrm{CO}_{2}$ treatments and protein and structural material extracts within our study. Additionally, fertilization did not significantly affect soil or fungal $\delta^{15} \mathrm{~N}$ values. The soil is a fine sandy loam classified as being from the Enon Series (fine, mixed, active, thermic Ultic Hapludalfs). The $\mathrm{pH}$ is
5.75 and derived from mafic bedrock. There are well-developed soil horizons with mixed clay mineralogy.

\section{Soil and Sporocarp Sampling}

Soils were collected in November 2010 and April 2013 using methods described in Hofmockel et al. (2011). Soils were separated by depth into organic Oi, Oea horizons, and mineral $0-15 \mathrm{~cm}$ and $15-30 \mathrm{~cm}$ horizons and then sieved to $2 \mathrm{~mm}$, dried and homogenized. Sporocarps were collected in October 2000, August and December of 2001, January, February, September, and November of 2002, October 2004, October 2010 and September and October of 2012. On each sampling day, each ring was surveyed and all sporocarps were collected. Whole sporocarps were dried, identified, and then homogenized to a fine powder and stored at room temperature until further analysis. Among the fungal groups, fungi with hydrophilic ectomycorrhizae (as noted in previous fungal literature) consisted of sporocarps from the genera Amanita, Chroogomphus, Hygrophorus, Inocybe, Laccaria, Lactarius, and 
Russula. Fungi with hydrophobic ectomycorrhizae (also as noted in fungal literature) consisted of sporocarps from the genera Cortinarius, Hydnellum, Sistotrema, Suillus, Tricholoma, and Tylopilus. Saprotrophic wood decay fungi consisted of the genera Gymnopilus, Gymnopus, Hypholoma, and Pluteus. Saprotrophic litter decay fungi consisted of the genera Agaricus, Clitocybe, Hygrocybe, Mycena, Ramariopsis, and Rhodocollybia (see Supplementary Material for species information). Due to low collection numbers in 2012, data from fertilized and unfertilized plots were included in our analysis of the effects of elevated $\mathrm{CO}_{2}$, and fertilization and the interactive effect of $\mathrm{CO}_{2}$ and fertilization were investigated as well. Samples collected from years before $\mathrm{CO}_{2}$ fumigation shutoff were also pooled due to low collection numbers in 2000, 2001, 2002, and 2010.

\section{Sporocarp Compound Extractions}

Chemical extractions were done for a subset of the sporocarps and focused on genera collected in 2012 that were most abundant, and for which we had multiple replicates per genus, specifically Amanita, Chroogomphus, Lactarius, Russula, Cortinarius, Hydnellum, Suillus, Tylopilus, Gymnopus, Ramariopsis, and Rhodocollybia. Approximately $200 \mathrm{mg}$ of sporocarp material was used to extract protein and structural material using a revised extraction method (Hobbie et al., 2013a). Ground sample was placed in borosilicate culture tubes with $3 \mathrm{~mL}$ of $n$-hexanes, capped and mixed. Tubes were incubated at $80^{\circ} \mathrm{C}$ for $30 \mathrm{~min}$ and then centrifuged at $2000 \mathrm{rpm}$ for $5 \mathrm{~min}$. Supernatant was discarded and the wash was repeated two or more times with $n$-hexanes. When the $n$-hexanes solvent was clear after mixing with the sample, final $n$-hexanes were discarded to remove all non-polar compounds and samples were dried down in a Genevac EZ-2.2 Series vacuum evaporator (Genevac Inc., New York, USA) at $45^{\circ} \mathrm{C}$. Subsequently, soluble polar compounds were removed by washing samples three or more times with $3 \mathrm{~mL}$ of $80 \%$ ethanol, using the same method as $n$-hexanes, until the solvent was clear when mixed with samples. After samples were dried down, proteins were hydrolyzed by adding $2 \mathrm{~mL}$ of $6 \mathrm{M} \mathrm{HCl}$ to the $n$-hexane-washed and ethanolwashed samples, agitated until mixed and incubated at $110^{\circ} \mathrm{C}$ for $24 \mathrm{~h}$. After hydrolysis, samples were dried down in the vacuum evaporator. Dried samples were then resuspended in $2 \mathrm{~mL}$ of $0.01 \mathrm{M} \mathrm{HCl}$ and sonicated for $30 \mathrm{~min}$. Tubes were then centrifuged at $2000 \mathrm{rpm}$ for $5 \mathrm{~min}$.

To separate protein and structural compounds the above extracts were washed through cation-exchange columns. Columns were first prepared by washing Dowex 50 WX8 200-400cl-mesh ion exchange resin with $80 \%$ ethanol, followed by $6 \mathrm{M} \mathrm{HCl}$ and then water until $\mathrm{pH}$ was restored to 6 . Washed ion exchange resin was placed into sterile $5 \mathrm{~mL}$ glass volumetric pipettes to the $4 \mathrm{~mL}$ line of the pipette. Columns were rinsed again two times with water, followed by the addition of the supernatant of the resuspended sample extract $(0.01 \mathrm{M} \mathrm{HCl})$ to the top of the column. Samples were first eluted with $24 \mathrm{~mL}$ of water to remove negatively charged and uncharged molecules. Hydrolyzed proteins were then eluted with $24 \mathrm{~mL}$ of $6 \mathrm{M}$ $\mathrm{HCl}$, collected and dried down in the vacuum evaporator. The remaining structural material pellet in the original sample tube was incubated with $2 \mathrm{~mL}$ of $2 \mathrm{M} \mathrm{NaOH}$ at $110^{\circ} \mathrm{C}$ for $2 \mathrm{~h}$. The tube was then centrifuged and the supernatant was discarded. The structural material was washed with water several times to remove $\mathrm{NaOH}$ and then dried in the vacuum evaporator.

\section{Isotope Analysis}

Ground soil, sporocarps, protein, and structural extracts were analyzed for $\% \mathrm{C}, \% \mathrm{~N}, \delta^{13} \mathrm{C}$, and $\delta^{15} \mathrm{~N}$ using a Costech 4010 Elemental Analyzer coupled to a Thermo Delta Plus XP IRMS at the University of New Hampshire. Standard deviations of laboratory standards (tuna, Underhill Oa, Underhill Bs, NIST 1515 apple leaves, and NIST 1575a pine needles) for $\delta^{15} \mathrm{~N}$ and $\delta^{13} \mathrm{C}$ averaged less than $0.2 \%$.

\section{Statistical Analysis}

Data were analyzed using JMP Pro 11 software (SAS, Cary, NC, USA). Fungal samples were treated as individual samples, without averaging by ring. Effects of $\mathrm{CO}_{2}$ treatment on $\delta^{15} \mathrm{~N}$ and $\delta^{13} \mathrm{C}$ of soils and fungi as well as differences between fungal types were explored using linear regression models. Factors of interest included $\mathrm{CO}_{2}$ fumigation, fertilization, and an interaction of the two factors as well as functional types for fungal data. Fertilization was also included to test whether samples from fertilized and unfertilized plots should be pooled. Experimental ring was included as a random effect. To identify factors that controlled differences in $\delta^{13} \mathrm{C}$ between protein and structural material, we used a stepwise linear regression model including $\mathrm{CO}_{2}$ fumigation, fertilization, bulk fungal $\delta^{15} \mathrm{~N}$ and $\delta^{13} \mathrm{C}$ and difference in protein and structural material $\delta^{15} \mathrm{~N}, \% \mathrm{~N}$, and $\% \mathrm{C}$.

\section{RESULTS}

\section{Soil $\delta^{13} \mathrm{C}$ and $\delta^{15} \mathrm{~N}$ Analysis}

Soils among all collected horizons were lower in $\delta^{13} \mathrm{C}$ in $\mathrm{CO}_{2}$ fumigated plots than in ambient plots both in 2010 during $\mathrm{CO}_{2}$ fumigation by a mean of $6.7 \%$ and in 2013 by $5.2 \% \cdot \mathrm{CO}_{2}$ fumigation significantly lowered soil $\delta^{13} \mathrm{C}(p<0.0001, n=84)$ while fertilization and the interaction between fumigation and fertilization did not significantly affect soil $\delta^{13} \mathrm{C}$ values. Depth also affected soil $\delta^{13} \mathrm{C}(p<0.0001, n=84)$ and response to $\mathrm{CO}_{2}$ fumigation, with $\delta^{13} \mathrm{C}$ of the Oi horizon in $\mathrm{CO}_{2}$-fumigated plots $5.5 \%$ lower in 2010 than in $2013(p=0.0150, n=10)$ (Figure 2). In the Oea horizon, $\delta^{13} \mathrm{C}$ of soils in $\mathrm{CO}_{2}$-fumigated plots was $1.6 \%$ lower in 2010 than in $2013(p=0.0213, n=10)$. In contrast, the $\delta^{13} \mathrm{C}$ of both mineral soil horizons $(0-15 \mathrm{~cm}$ and $15-30 \mathrm{~cm})$ did not change between 2010 and 2013. Fertilization and the interaction of fertilization with fumigation were not significant factors ( $p=0.9232$ and 0.8109 , respectively). In 2010, the Oi horizon was the most ${ }^{13} \mathrm{C}$-depleted horizon in $\mathrm{CO}_{2}$-fumigated plots, while in 2013 the Oea horizon was the most ${ }^{13} \mathrm{C}$-depleted horizon.

To clarify sources of fungal carbon and determine whether carbon from soil organic ( $\mathrm{C}: \mathrm{N}$ bonded) matter was acquired from the younger Oi or older Oea horizons, soil $\delta^{15} \mathrm{~N}$ was also investigated. $\mathrm{CO}_{2}$ treatment and fertilization did not significantly affect soil $\delta^{15} \mathrm{~N}$, but depth of soil was a significant factor $(0.0058$, 


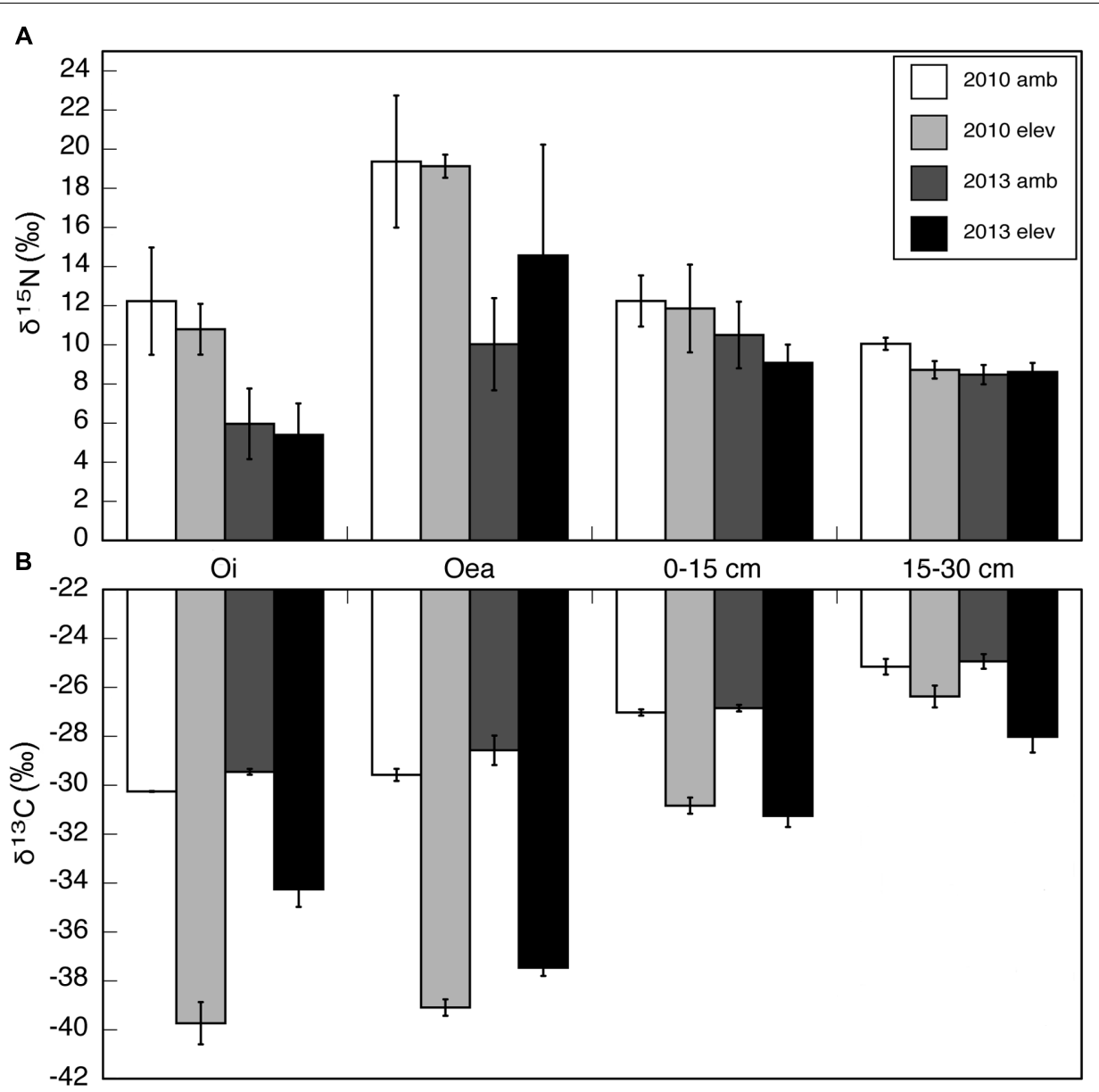

FIGURE 2 | (A) $\delta^{15} \mathrm{~N}$ and (B) $\delta^{13} \mathrm{C}$ of soils collected in 2010 during $\mathrm{CO}_{2}$ fumigation and in 2013 three years after $\mathrm{CO}_{2}$ fumigation shutoff in both ambient and $\mathrm{CO}_{2}$-fumigated plots. Soils were separated at the Oi and Oea organic horizons and at 0-15 and 15-30 cm depths. Each bar represents an average of four replicates in 2010 and three replicates in 2013. Error bars indicate SE.

$n=84)$. The Oea horizon was enriched in ${ }^{15} \mathrm{~N}$ relative to the $\mathrm{Oi}$ horizon by $6.4 \%$ in 2010 and by $5.3 \%$ in 2013 (Figure 2).

\section{Bulk $\delta^{13} \mathrm{C}$ Analysis}

During $\mathrm{CO}_{2}$ fumigation in 2010, fungal functional type and fumigation significantly affected bulk $\delta^{13} \mathrm{C}(p<0.0001$ for both, $n=245$ ). All fungal types had lower $\delta^{13} \mathrm{C}$ in $\mathrm{CO}_{2}$-fumigated plots than in ambient plots, with the largest difference in sporocarps of fungi with hydrophilic ectomycorrhizae $(-11.4 \% 0)$, followed by hydrophobic ectomyorrhizae $(-10.6 \% 0)$, saprotrophic litter decay fungi $(-9.0 \% 0)$ and wood decay $(-4.1 \% 0)$ fungi (Table 1). In $\mathrm{CO}_{2}$-fumigated plots, $\delta^{13} \mathrm{C}$ was 3.1 to $8.1 \%$ higher for fungi with hydrophobic ectomycorrhizae and 4.5 to $9.5 \%$ higher for fungi with hydrophilic ectomycorrhizae than for litter decay fungi and wood decay fungi. In 2012, 2 years after $\mathrm{CO}_{2}$ fumigation shutoff, fungal type and fumigation continued to significantly affect bulk $\delta^{13} \mathrm{C}(p=0.0004$ and $<0.0001$ respectively, $n=86)$. Litter decay and wood decay fungi from $\mathrm{CO}_{2}$-fumigated plots reflected ${ }^{13} \mathrm{C}$ patterns in the $\mathrm{Oi}$ and Oea soil horizons and were still 5.8 and $8.6 \%$ lower in $\delta^{13} \mathrm{C}$ than sporocarps from ambient plots, respectively (Table 1). Two years after $\mathrm{CO}_{2}$ fumigation shutoff, ectomycorrhizal sporocarps had increased by 10 to $11 \%$ in ${ }^{13} \mathrm{C}$ in formerly $\mathrm{CO}_{2}$-fumigated plots. Fertilization and the interaction with fumigation did not significantly affect bulk $\delta^{13} \mathrm{C}$ before or after $\mathrm{CO}_{2}$ fumigation shutoff.

\section{Protein and Structural Sporocarp $\delta^{13} \mathrm{C}$ Analysis}

We analyzed protein and structural material of sporocarps collected 2 years after $\mathrm{CO}_{2}$ shutoff. $\mathrm{CO}_{2}$ fumigation and fungal functional type significantly affected protein $\delta^{13} \mathrm{C}(p=0.0253$ and 0.0153 respectively, $n=37$ ), while fertilization and the interaction of $\mathrm{CO}_{2}$ fumigation with fertilization were not significant factors. Protein $\delta^{13} \mathrm{C}$ of sporocarps with hydrophobic ectomycorrhizae was $2.1 \%$ lower in $\mathrm{CO}_{2}$-fumigated plots than in ambient plots (Table 2; Figure 3). Protein of litter fungi was also lower in $\delta^{13} \mathrm{C}$ in $\mathrm{CO}_{2}$-fumigated plots by $6.1 \%$. Resolution of protein and structural material from wood decay fungi was poor and standard error was high due to a low number of samples $(n=3)$. Only fungal functional type significantly affected 
TABLE 1 | $\delta^{13} \mathrm{C}$ for bulk sporocarps of fungi with hydrophilic ectomycorrhizae (Hi), hydrophobic ectomycorrhizae (Ho), saprotrophic litter decay (Id), and wood decay (wd) collected in ambient and $\mathrm{CO}_{2}$-fumigated plots at the Duke Forest FACE site during $\mathrm{CO}_{2}$ fumigation in 2010 and 2 years after $\mathrm{CO}_{2}$ fumigation shutoff.

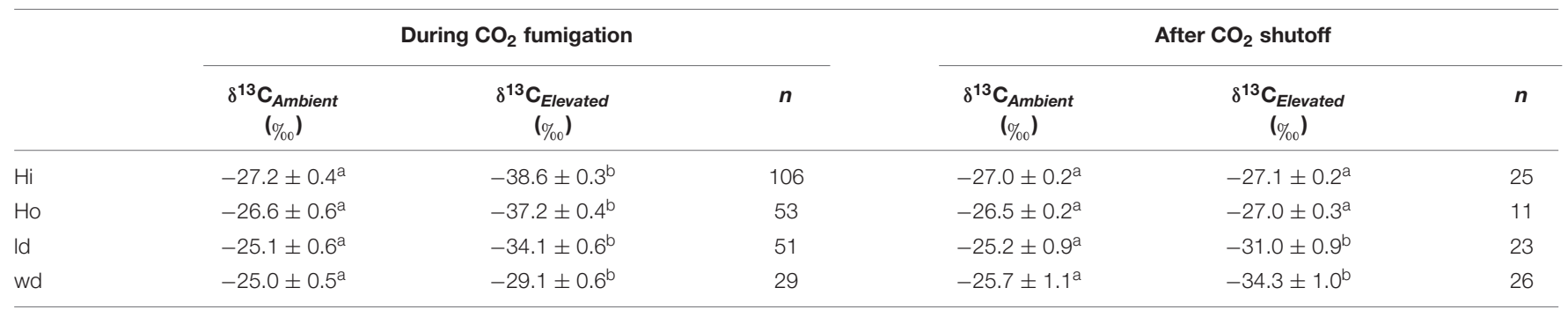

Significant differences in values due to FACE treatment effects during $\mathrm{CO}_{2}$ fumigation and after $\mathrm{CO}_{2}$ fumigation shutoff are shown for $P<0.1$.

TABLE $2 \mid \delta^{13} \mathrm{C}$ for protein and structural material of sporocarps and the $\delta^{13} \mathrm{C}$ difference between the two $\left(\delta^{13} \mathrm{C}_{\text {pro-struc }}\right)$ for fungi with hydrophilic ectomycorrhizae (Hi), hydrophobic ectomycorrhizae (Ho), and saprotrophic sporocarps, specifically litter decay (Id) and wood decay (wd) fungi, collected in ambient and $\mathrm{CO}_{2}$-fumigated plots at the Duke Forest FACE site 2 years after $\mathrm{CO}_{2}$ fumigation shutoff.

\begin{tabular}{|c|c|c|c|c|c|c|c|}
\hline After $\mathrm{CO}_{2}$ shutoff & \multicolumn{2}{|c|}{ Protein material } & \multicolumn{2}{|c|}{ Structural material } & \multicolumn{3}{|c|}{ Protein/Structural } \\
\hline $\mathrm{Hi}$ & $-24.1 \pm 0.4^{a}$ & $-24.6 \pm 0.3^{a}$ & $-27.8 \pm 0.6^{a}$ & $-28.8 \pm 0.4^{a}$ & $3.6 \pm 0.6^{a}$ & $4.2 \pm 0.4^{\mathrm{a}}$ & 20 \\
\hline $\mathrm{Ho}$ & $-21.9 \pm 0.5^{\mathrm{a}}$ & $-24.0 \pm 0.3^{b}$ & $-27.7 \pm 0.5^{a}$ & $-27.8 \pm 0.3^{a}$ & $5.7 \pm 0.8^{a}$ & $3.8 \pm 0.5^{b}$ & 7 \\
\hline Id & $-22.6 \pm 0.8^{a}$ & $-28.7 \pm 1.0^{b}$ & $-28.1 \pm 0.7^{a}$ & $-33.9 \pm 0.8^{b}$ & $5.5 \pm 0.6^{a}$ & $5.2 \pm 0.7^{\mathrm{a}}$ & 7 \\
\hline
\end{tabular}

Significant differences in values due to FACE treatment effects are shown for $P<0.05$ for protein and structural material and $P<0.1$ for protein/structural material.

$\delta^{13} \mathrm{C}$ of structural material and structural material only differed in $\delta^{13} \mathrm{C}$ between ambient and $\mathrm{CO}_{2}$-fumigated plots for litter decay fungi (Table 2; Figure 3). In addition, in ambient plots, protein of fungi with hydrophilic ectomycorrhizae was lower in $\delta^{13} \mathrm{C}$ than protein of fungi with hydrophobic ectomycorrhizae, litter fungi, and wood decay fungi by $2.4,1.5$, and $1.9 \%$, respectively.

The ${ }^{13} \mathrm{C}$ enrichment of protein relative to structural material $\left(\delta^{13} \mathrm{C}_{\text {pro-struc }}\right)$ of fungi with hydrophobic ectomycorrhizae was $3.8 \%$ in $\mathrm{CO}_{2}$-fumigated plots and $5.7 \%$ in ambient plots (Table 2). Controls over $\delta^{13} \mathrm{C}_{\text {pro-struc }}$ across treatment and fungal type were investigated using stepwise multiple regressions (Table 3). Bulk sporocarp $\delta^{13}$ and $\delta^{15} \mathrm{~N}$ and $\% \mathrm{~N}_{\text {pro-struc }}$ were significant factors that accounted for $29.56,28.30$, and $18.39 \%$ of the variance, respectively. The adjusted $r^{2}$ versus the independent variables was 0.547 for $\delta^{13} C_{\text {pro-struc }}$ (overall $p=0.0002$ ).

\section{DISCUSSION}

Identifying sources of carbon is important for distinguishing different functional types of fungi. Stable isotope analysis of bulk fungal tissue has been used to determine that ectomycorrhizal and saprotrophic fungi rely primarily on litter and photosynthates as carbon sources (Hobbie et al., 2001, 2014; Mayor et al., 2009). Isotopic relationships between bulk sporocarps collected in ambient and $\mathrm{CO}_{2}$-fumigated plots in a previous Duke FACE collection also suggested that ectomycorrhizal fungi derived carbon from soil and litter (Hobbie et al., 2014). Here, we clarified fungal sources of carbon that are difficult to detect in bulk tissue isotope analysis by combining information from bulk tissue, protein and structural extracts of sporocarps from the Duke FACE experiment.

As predicted, bulk sporocarps from all four functional classes collected during ${ }^{13} \mathrm{C}$-depleted $\mathrm{CO}_{2}$ fumigation were low in $\delta^{13} \mathrm{C}$ relative to ambient samples, while only saprotrophic fungi maintained low $\delta^{13} \mathrm{C}$ signatures after $\mathrm{CO}_{2}$ shutoff. The persistently low bulk $\delta^{13} \mathrm{C}$ of wood decay fungi and litter decay fungi from $\mathrm{CO}_{2}$-fumigated plots 2 years after fumigation shutoff indicated that these fungi relied on surficial litter and wood produced during $\mathrm{CO}_{2}$ fumigation. The smaller difference in $\delta^{13} \mathrm{C}$ between pre-fumigation and post-fumigation samples of wood decay fungi than of litter decay fungi also suggested that wood decay fungi may use carbon that was produced before $\mathrm{CO}_{2}$ fumigation was initiated, as wood $\mathrm{C}$ sources can be relatively old. The increased $\delta^{13} \mathrm{C}$ of fungi with hydrophobic and hydrophilic ectomycorrhizae in $\mathrm{CO}_{2}$-fumigated plots 2 years after fumigation shutoff and similar values to fungi in ambient plots indicate that these functional groups relied on recent plant photosynthate that was produced after fumigation as a carbon source. However, these bulk tissue results lack sufficient sensitivity to assess our hypothesis that ectomycorrhizal fungi access carbon in soil-derived organic nitrogen pools, which are present in deeper soil horizons and ${ }^{13} \mathrm{C}$-enriched relative to other carbon pools.

In contrast to bulk analyses, combined carbon and nitrogen isotopic analysis of fungal protein of sporocarps collected 2 years after $\mathrm{CO}_{2}$ fumigation shutoff supported our hypothesis that fungi with hydrophobic ectomycorrhizae use soil-derived organic 


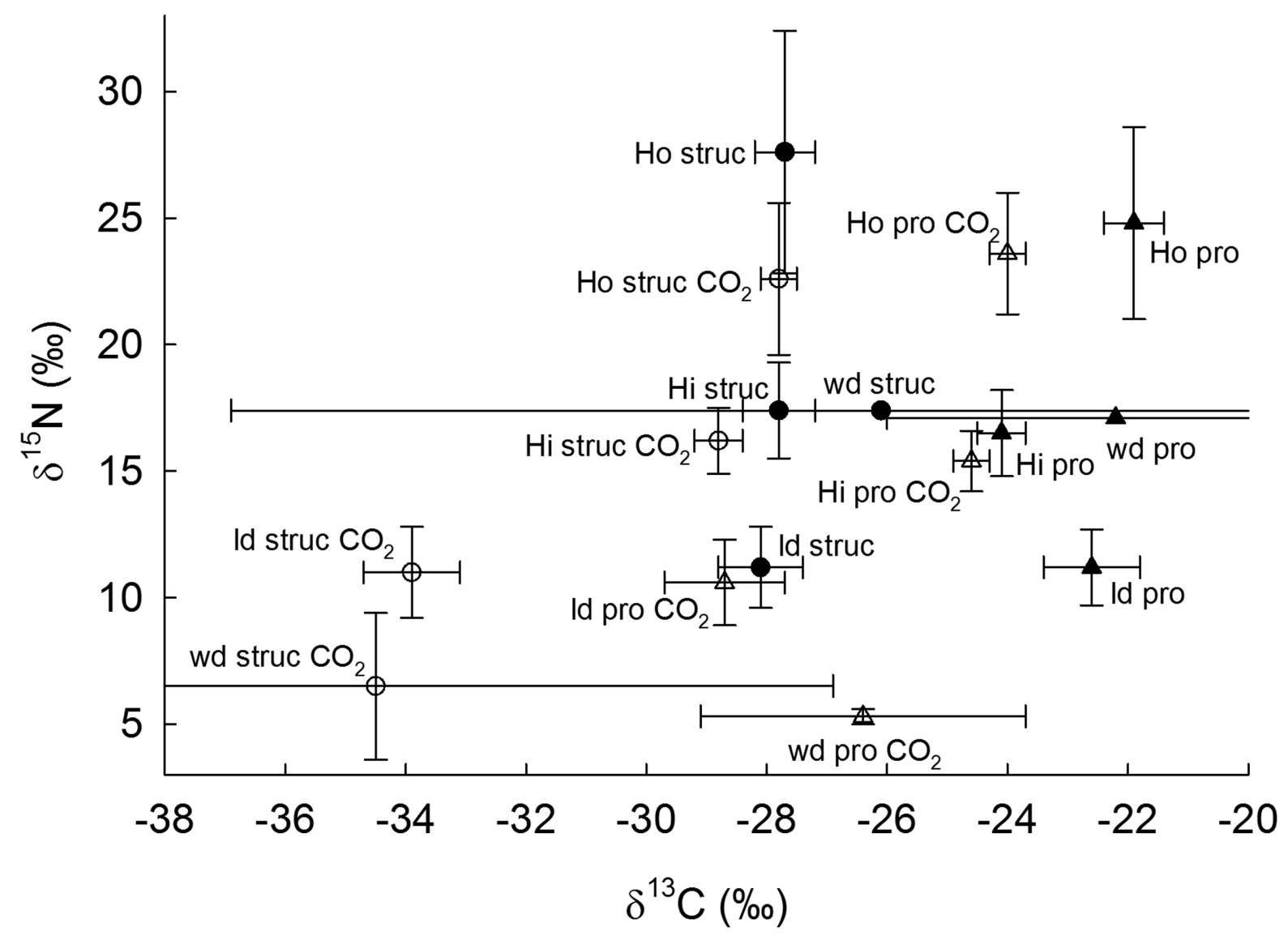

FIGURE $3 \mid \delta^{13} \mathrm{C}$ and $\delta^{15} \mathrm{~N}$ of sporocarps of fungi with hydrophobic ectomycorrhizae (Ho) and hydrophilic ectomycorrhizae (Hi) as well as saprotrophic wood decay (wd) and litter decay (Id) fungi collected in ambient (filled symbols) and $\mathrm{CO}_{2}$-fumigated plots (CO ${ }_{2}$, open symbols) at the Duke Forest FACE site 2 years after $\mathbf{C O}_{2}$ fumigation shutoff. Error bars indicate SE.

TABLE 3 | Controls over $\delta^{13} \mathrm{C}_{\text {pro-struc }}(n=27)$ were investigated using stepwise multiple regressions.

\begin{tabular}{lccc}
\hline & \multicolumn{3}{c}{$\delta^{\mathbf{1 3}} \mathbf{C}_{\text {pro-struc }}$ coefficient } \\
\cline { 2 - 4 } Independent variable & Estimate (\%o) & $\%$ variance & $\boldsymbol{p}$ \\
\hline Bulk $\delta^{13} \mathrm{C}$ & $-0.27 \pm 0.10$ & 29.56 & 0.0095 \\
Bulk $\delta^{15} \mathrm{~N}$ & $-0.16 \pm 0.06$ & 28.30 & 0.0109 \\
$\% \mathrm{~N}_{\text {pro-struc }}$ & $-0.30 \pm 0.13$ & 18.39 & 0.0354 \\
Functional group (Hi \& ld-Ho) & $-1.48 \pm 0.58$ & 23.76 & 0.0183 \\
\hline
\end{tabular}

The model explained 0.547 of the variance $(p=0.0002)$. The $\%$ variance is the $\%$ of explained variance attributed to the specified independent variable in the regression. $P$-values are italicized when $P<0.05$.

nitrogen sources, such as humic substances, proteinaceous materials, amino sugars and heterocyclic nitrogen compounds, for protein carbon. In ambient plots, protein from both litter decay fungi and fungi with hydrophobic ectomycorrhizae were enriched in ${ }^{13} \mathrm{C}$ relative to protein from wood decay fungi and fungi with hydrophilic ectomycorrhizae, suggesting that the former fungi used carbon from relatively older and deeper ${ }^{13} \mathrm{C}$-enriched organic soil pools. The ${ }^{13} \mathrm{C}$-depleted values of protein from fungi with hydrophilic ectomycorrhizae relative to fungi with hydrophobic ectomycorrhizae in ambient plots suggest that carbon from recent plant photosynthate was incorporated into protein of fungi with hydrophilic ectomycorrhizae. Furthermore, in plots previously exposed to elevated $\mathrm{CO}_{2}$, protein of litter decay fungi and fungi with hydrophobic ectomycorrhizae was depleted in ${ }^{13} \mathrm{C}$ relative to ambient plots, also suggesting that these fungal groups assimilate older organic nitrogen that was synthesized during $\mathrm{CO}_{2}$ fumigation years. However, $\delta^{15} \mathrm{~N}$ patterns in protein revealed that fungi with hydrophobic ectomycorrhizae use older organic nitrogen than litter decay fungi, since protein of ectomycorrhizal fungi was ${ }^{15} \mathrm{~N}$-enriched relative to saprotrophic fungi, resembling the ${ }^{15} \mathrm{~N}$-enriched organic nitrogen in the older Oea soil horizon more than the Oi soil horizon. Although ectomycorrhizal fungi are higher in $\delta^{15} \mathrm{~N}$ than saprotrophic fungi due to ${ }^{15} \mathrm{~N}$ enrichment during transfer of ${ }^{15} \mathrm{~N}$-depleted nitrogen to plants (Hobbie and Colpaert, 2003), the 5\% higher $\delta^{15} \mathrm{~N}$ of protein of fungi with hydrophobic ectomycorrhizae compared to fungi with hydrophilic ectomycorrhizae also supports our hypothesis that fungi with hydrophobic ectomycorrhizae use older ${ }^{15} \mathrm{~N}$-enriched pools of organic nitrogen. 
Although exploration of the effect of genus in addition to functional type on fungal isotopic response to $\mathrm{CO}_{2}$ fumigation would have provided additional information on the role of different fungi in carbon cycling, this was beyond the scope of our study due to the limited number and variety of sporocarps that generated within experimental plots. Regardless, our results support prior results on radiocarbon of protein of ectomycorrhizal fungal protein indicating that fungi with hydrophobic ectomycorrhizae use older organic nitrogen sources than fungi with hydrophilic ectomycorrhizae (Hobbie et al., 2013a). These isotopic carbon patterns likely arise from differences in enzymatic capacity and preference for insoluble or soluble substrates between hydrophobic and hydrophilic ectomycorrhizae (Lilleskov et al., 2011; Hobbie et al., 2013b). Although the ${ }^{13} \mathrm{C}$ enrichment of saprotrophic wood and litter decay protein relative to hydrophilic protein in ambient plots suggests use of organic nitrogen by saprotrophic fungi, these patterns could also be derived from litter or wood cellulose and de novo synthesis of fungal amino acids. Therefore, further investigation is needed of carbon sources for protein and structural material of saprotrophic fungi, such as with separate ${ }^{13} \mathrm{C}$ labeling of plant cellulose and organic nitrogen, in order to determine the effect of fungal preference for different carbon substrates as well as age of carbon substrates on fungal isotopic patterns.

The $\delta^{13} \mathrm{C}$ of structural material of fungi with hydrophobic and hydrophilic ectomycorrhizae suggests that ectomycorrhizal fungi rely solely on recent plant photosynthates for structural carbon, since the low $\delta^{13} \mathrm{C}$ from $\mathrm{CO}_{2}$ fumigation did not persist 2 years after $\mathrm{CO}_{2}$ shutoff. Additionally, the $\delta^{13} \mathrm{C}$ of structural material of saprotrophic fungi was $5 \%$ lower than ectomycorrhizal fungi, since litter decay fungi rely heavily on surficial litter that persisted after $\mathrm{CO}_{2}$ shutoff as a carbon source.

The $\delta^{13} \mathrm{C}_{\text {pro-struc }}$ ranged from 3.6 to $5.7 \%$, overlapping the estimated range of ${ }^{13} \mathrm{C}$ enrichment between protein and structural carbohydrates of $4.2 \pm 0.5 \%$ in Hobbie et al. (2012). Similar to this previous study on protein and carbohydrate content in caps and stipes of sporocarps, nitrogen content and $\delta^{15} \mathrm{~N}$ between protein and structural material correlated with $\delta^{13} \mathrm{C}_{\text {pro-struc }}$ in the current study. We previously hypothesized that ${ }^{13} \mathrm{C}$ differences between fungal protein and carbohydrates could primarily be due to differences in carbon metabolism (Hobbie et al., 2012). Specifically, ${ }^{13} \mathrm{C}$ fractionation and loss of ${ }^{13} \mathrm{C}$-depleted $\mathrm{CO}_{2}$ was hypothesized during production of carbon skeletons from the tricarboxylic acid cycle for protein synthesis (O'Leary and Yapp, 1978; Grissom and Cleland, 1988; Tcherkez et al., 2003). However, correlation of nitrogen content and $\delta^{15} \mathrm{~N}$ with $\delta^{13} \mathrm{C}$ of protein and structural material in our data suggests that nitrogen source is also an important factor. Differences in $\delta^{13} \mathrm{C}_{\text {pro-struc }}$ between ambient and previously $\mathrm{CO}_{2}$-fumigated plots for fungi with hydrophobic ectomycorrhizae also suggest that these materials have different carbon sources. If ${ }^{13} \mathrm{C}$ enrichment of protein were due to internal fractionation rather than differences in $\mathrm{C}$ source, $\delta^{13} \mathrm{C}_{\text {pro-struc }}$ should be the same for ambient and $\mathrm{CO}_{2}$-fumigated plots. Although
${ }^{13} \mathrm{C}_{\text {pro-struc }}$ was similar for ambient and $\mathrm{CO}_{2}$-fumigated plots in saprotrophic fungi and fungi with hydrophilic ectomycorrhizae, likely due to the use of more recently produced carbon sources, $\delta^{13} \mathrm{C}_{\text {pro-struc }}$ of fungi with hydrophobic ectomycorrhizae was lower by $1.9 \%$ in plots that were previously fumigated with elevated $\mathrm{CO}_{2}$. This difference between protein and structural material of hydrophobic ectomycorrhizal fungi in ambient and $\mathrm{CO}_{2}$ fumigation treatments indicates that, in $\mathrm{CO}_{2}$-fumigated plots, the ${ }^{13} \mathrm{C}$-depleted carbon in protein was derived from soil organic nitrogen that was synthesized during $\mathrm{CO}_{2}$ fumigation. Our results therefore indicate that fungi with hydrophobic ectomycorrhizae use both organic nitrogen and recent photosynthate as a carbon source. However, this should be investigated further with more fungi with hydrophobic and hydrophilic ectomycorrhizae.

Movement of recently fixed carbon is rapid through plants and the sporocarp $\delta^{13} \mathrm{C}$ of ectomycorrhizal fungi returned to natural levels as quickly as $2-3$ months after pulse ${ }^{13} \mathrm{C}$ labeling of host plants (Högberg et al., 2010). Isotopic differences in $\mathrm{CO}_{2}$-fumigated plots between ectomycorrhizal and saprotrophic fungi during and after fumigation therefore probably appeared shortly after fumigation shutoff. This difference could be used to identify compounds derived from recent photosynthate. However, the 2-year period after $\mathrm{CO}_{2}$ fumigation shutoff in this study also allowed us to identify which functional groups were assimilating newly produced photosynthate, young organic nitrogen in surficial litter or old organic nitrogen sources in deeper soils. Future studies in global change experiments of $\delta^{13} \mathrm{C}$ values of bulk tissue, protein and structural material before $\mathrm{CO}_{2}$ fumigation, shortly after fumigation shutoff and a few years after fumigation shutoff can accordingly further help to clarify fungal sources of carbon.

\section{CONCLUSION}

Our data demonstrate that protein and structural material can use different carbon pools and that patterns of carbon use differ among fungi with hydrophilic ectomycorrhizae, fungi with hydrophobic ectomycorrhizae, and saprotrophic fungi. Specifically, fungi with hydrophilic ectomycorrhizae used recent plant photosynthate and young organic matter for carbon while fungi with hydrophobic ectomycorrhizae mined old organic material for protein carbon and converted recent plant photosynthate into structural material. These results demonstrate that prior inferences about differences in organic nitrogen partitioning of fungi with hydrophobic and hydrophilic ectomycorrhizae reported from boreal forests (Hobbie et al., 2013a) apply to a much warmer temperate forest ecosystem as well. Our data also demonstrate for the first time that litter decay fungi used young organic matter carbon for both protein and structural material.

\section{AUTHOR CONTRIBUTIONS}

JC is the primary author and conducted the laboratory and data analysis of this study. $\mathrm{KH}$ provided samples and the 
experimental site. EH provided samples and the initial concept for this study. All authors contributed to the composition of this manuscript.

\section{FUNDING}

This work was supported by grant DEB-1146328 from the US National Science Foundation (NSF) and grant ER65430 from the US Department of Energy. Core funding for the Duke FACE site was provided by the Office of Science (BER), US Department of Energy, grant no. DE-FG02-95ER62083.

\section{REFERENCES}

Agerer, R. (2006). Fungal relationships and structural identity of their ectomycorrhizae. Mycol. Progress 5, 67-107. doi: 10.1007/s11557-0060505-x

Bago, B., Chamberland, H., Goulet, A., Vierheilig, H., Lafontaine, J. G., and Piche, E. (1996). Effect of nikkomycin Z, a chitin synthase inhibitor, on hyphal growth and cell wall structure of two arbuscular-mycorrhizal fungi. Protoplasma 1992, 80-92. doi: 10.1007/BF01273247

Billings, S. A., and Richter, D. D. (2006). Changes in stable isotopic signatures of soil nitrogen and carbon during 40 years of forest development. Oecologia 148, 325-333. doi: 10.1007/s00442-006-0366-7

Bowman, S. M., and Free, S. J. (2006). The structure and synthesis of the fungal cell wall. Bioessays 28, 799-808. doi: 10.1002/bies.20441

Colpaert, J., van Laere, A., and van Assche, J. A. (1996). Carbon and nitrogen allocation in ectomycorrhizal and non-mycorrhizal Pinus sylvestris L. seedlings. Tree Physiol. 16, 787-793. doi: 10.1093/treephys/16.9.787

González-Chávez, M. C., Carrillo-González, R., Wright, S. F., and Nichols, K. A. (2004). The role of glomalin, a protein produced by arbuscular mycorrhizal fungi in sequestering potentially toxic elements. Environ. Pollut. 130, 317-323. doi: 10.1016/j.envpol.2004.01.004

Grissom, C. B., and Cleland, W. W. (1988). Isotope effect studies of the chemical mechanism of pig-heart NADP isocitrate dehydrogenase. Biochemistry 27, 2934-2943. doi: 10.1021/bi00408a040

Hendrey, G. R., Ellsworth, D. S., Lewin, K. F., and Nagy, J. (1999). A free-air enrichment system for exposing tall forest vegetation to elevated atmospheric CO2. Glob. Change Biol. 5, 293-309. doi: 10.1046/j.1365-2486.1999. 00228.x

Ho, I., and Trappe, J. M. (1973). Translocation of 14C from Festuca plants to their endomycorrhizal fungi. Nat. New Biol. 244, 30-31. doi: 10.1038/ newbio244030a0

Hobbie, E. A., and Colpaert, J. V. (2003). Nitrogen availability and colonization by mycorrhizal fungi correlate with nitrogen isotope patterns in plants. New Phytol. 157, 115-126. doi: 10.1046/j.1469-8137.2003.00657.x

Hobbie, E. A., Hofmockel, K. S., Van Diepen, L. T. A., Lilleskov, E. A., Ouimette, A. P., and Finzi, A. C. (2014). Fungal carbon sources in a pine forest: evidence from a 13C-labeled global change experiment. Fungal Ecol. 10, 91-100. doi: $10.1111 /$ nph. 12578

Hobbie, E. A., and Ouimette, A. P. (2009). Controls of nitrogen isotope patterns in soil profiles. Biogeochemistry 95, 355-371. doi: 10.1111/j.1469-8137.2012. 04300.x

Hobbie, E. A., Ouimette, A. P., Schuur, E. A. G., Kierstead, D., Trappe, J. M., Bendiksen, K., et al. (2013a). Radiocarbon evidence for the mining of organic nitrogen from soil by mycorrhizal fungi. Biogeochemistry 114, 381-389.

Hobbie, E. A., Sanchez, F. S., and Rygiewicz, P. T. (2004). Carbon use, nitrogen use, and isotopic fractionation of ectomycorrhizal and saprotrophic fungi in natural abundance and 13C -labelled cultures. Mycol. Res. 108, 725-736. doi: $10.1017 /$ S0953756204000590

Hobbie, E. A., Sánchez, F. S., and Rygiewicz, P. T. (2012). Controls of isotopic patterns in saprotrophic and ectomycorrrhizal fungi. Soil Biol. Biochem. 48, 60-68. doi: 10.1016/j.soilbio.2012.01.014

\section{ACKNOWLEDGMENT}

We thank Linda van Diepen and Erik Lilleskov for providing 2010 sporocarp samples and thank Linda for internal manuscript peer review.

\section{SUPPLEMENTARY MATERIAL}

The Supplementary Material for this article can be found online at: http://journal.frontiersin.org/article/10.3389/fmicb. 2016.01994/full\#supplementary-material

Hobbie, E. A., van Diepen, L. T. A., Lilleskov, E. A., Ouimette, A. P., Finzi, A. C., and Hofmockel, K. S. (2013b). Fungal functioning in a pine forest: evidence from a 15N-labeled global change experiment. New Phytol. 201, 1431-1439. doi: $10.1111 / \mathrm{nph} .12578$

Hobbie, E. A., Weber, N. S., and Trappe, J. M. (2001). Mycorrhizal vs saprotrophic status of fungi: the isotopic evidence. New Phytol. 150, 601-610. doi: 10.1007/ s00572-010-0355-x

Hofmockel, K. S., Gallet-Budynek, A., McCarthy, H. R., Currie, W. S., Jackson, R. B., and Finzi, A. (2011). Sources of increased N uptake in forest trees growing under elevated CO2: results of a large-sale $15 \mathrm{~N}$ study. Glob. Change Biol. 17, 3338-3350. doi: 10.1111/j.1365-2486.2011.02465.x

Högberg, M. N., Briones, M. J. I., Keel, S. G., Metcalfe, D. B., Campbell, C., Midwood, A. J., et al. (2010). Quantification of effects of season and nitrogen supply on tree below-ground carbon transfer to ectomycorrhizal fungi and other soil organisms in a boreal pine forest. New Phytol. 187, 485-493. doi: 10.1111/j.1469-8137.2010.03274.x

Högberg, P., Plamboeck, A. H., Taylor, A. F. S., and Fransson, P. M. A. (1999). Natural 13C abundance reveals trophic status of fungi and host-origin of carbon in mycorrhizal fungi in mixed forests. Proc. Natl. Acad. Sci. U.S.A. 96, 8534-8539. doi: 10.1073/pnas.96.15.8534

Kalač, P. (2009). Chemical composition and nutritional value of European species of wild growing mushrooms: a review. Food Chem. 113, 9-16. doi: 10.1080/ 10590500802350086

Kohzu, A., Yoshioka, T., Ando, T., Takahashi, M., Koba, K., and Wada, E. (1999). Natural $13 \mathrm{C}$ and $15 \mathrm{~N}$ abundance of field-collected fungi and their ecological implications. New Phytol. 144, 323-330. doi: 10.1046/j.1469-8137.1999. 00508.x

Lilleskov, E. A., Hobbie, E. A., and Horton, T. R. (2011). Conservation of ectomycorrhizal fungi: exploring the linkages between functional and taxonomic responses to anthropogenic N deposition. Fungal Ecol. 4, 174-183. doi: 10.1016/j.funeco.2010.09.008

Lindahl, B. D., Ihrmark, K., Boberg, J., Trumbore, S. E., Högberg, P., Stenlid, J., et al. (2007). Spatial separation of litter decomposition and mycorrhizal nitrogen uptake in a boreal forest. New Phytol. 173, 611-620. doi: 10.1111/j.1469-8137. 2006.01936.x

Mayor, J. R., Schuur, E. A. G., and Henkel, T. W. (2009). Elucidating the nutritional dynamics of fungi using stable isotopes. Ecol. Lett. 12, 171-183. doi: 10.1111/j. 1461-0248.2008.01265.x

Nadelhoffer, K. J., and Fry, B. (1988). Controls on natural N-15 and C-13 abundances in forest soil organic-matter. Soil Sci. Soc. Am. J. 52, 1633-1640. doi: $10.2136 /$ sssaj1988.03615995005200060024x

Niessing, D. (2000). RNA-Binding Proteins in Fungi and Their Role in MRNA Localization. Austin, TX: Landes Bioscience.

O’Leary, M. H., and Yapp, C. J. (1978). Equilibrium carbon isotope effect on a decarboxylation reaction. Biochem. Biophys. Res. Commun. 80, 155-160. doi: 10.1016/0006-291X(78)91117-8

Persson, I., Tjerneld, F., and Hahn-Hägerdal, B. (1991). Fungal celllulolytic enzyme production: a review. Process Biochem. 26, 65-74. doi: 10.1016/0032-9592(91) 80019-L

Rayner, A. D. M., and Boddy, L. (1988). Fungal Decomposition of Wood, its Biology and Ecology. Chichester: John Wiley and Sons Ltd. 
Saier, M. H. Jr. (2000). Families of transmembrane transporters selective for amino acids and their derivatives. Microbiology 146, 1775-1795. doi: 10.1099/ 00221287-146-8-1775

Seidl, V. (2008). Chitinases of filamentous fungi: a large group of diverse proteins with multiple phydiological functions. Fungal Biol. Rev. 22, 36-42. doi: 10.1016/ j.fbr.2008.03.002

Smith, S. E., and Read, J. G. (1997). Mycorrhizal Symbiosis. San Diego CA: Academic Press Inc.

Tcherkez, G., Nogués, S., Bleton, J., Cornic, G., Badeck, F., and Ghashghaie, J. (2003). Metabolic origin of carbon isotope composition of leaf dark-respired $\mathrm{CO} 2$ in French bean. Plant Physiol. 164, 317-335.

Tinker, P. B., Jones, M. D., and Durall, D. M. (1990). Phosphorus and carbon relationships in willow ectomycorrhizae. Symbiosis 9, 43-49.
Unestam, T., and Sun, Y. P. (1995). Extramatrical structures of hydrophobic and hydrophilic ectomycorrhizal fungi. Mycorrhiza 5, 301-311. doi: 10.1007/ BF00207402

Conflict of Interest Statement: The authors declare that the research was conducted in the absence of any commercial or financial relationships that could be construed as a potential conflict of interest.

Copyright (c) 2016 Chen, Hofmockel and Hobbie. This is an open-access article distributed under the terms of the Creative Commons Attribution License (CC BY). The use, distribution or reproduction in other forums is permitted, provided the original author(s) or licensor are credited and that the original publication in this journal is cited, in accordance with accepted academic practice. No use, distribution or reproduction is permitted which does not comply with these terms. 